Digitized by the Internet Archive in 2016 


\title{
The 2001 International Piping Plover Census in Alberta
}

\author{
David R. C. Prescott
}

Alberta Species at Risk Report No. 27

November 2001

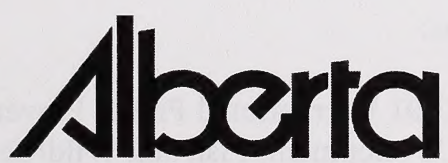

SUSTAINABLE RESOURCE

DEVELOPMENT 
Publication No.: I/040

ISBN: 0-7785-1849-3 (Printed Edition)

ISBN: 0-7785-1850-7 (On-line Edition)

ISSN: 1496-7219 (Printed Edition)

ISSN: 1496-7146 (On-line Edition)

Illustration: Brian Huffman

For copies of this report, contact:

Information Centre - Publications

Alberta Environment / Alberta Sustainable Resource Development

Main Floor, Great West Life Building

9920108 Street

Edmonton, Alberta, Canada T5K 2M4

Telephone: (780) 422-2079

\section{OR}

Information Service

Alberta Environment / Alberta Sustainable Resource Development \#100, 311512 Street NE

Calgary, Alberta, Canada T2E 7J2

Telephone: (403) 297-3362

\section{OR}

Visit our web site at:

http://www3.gov.ab.ca/srd/fw/riskspecies/

This publication may be cited as:

Prescott, D. R. C. 2001. The 2001 International Piping Plover Census in Alberta. Alberta Sustainable Resource Development, Fish and Wildlife Division, Alberta Species at Risk Report No. 27, Edmonton, AB. 15 pp. 
TABLE OF CONTENTS

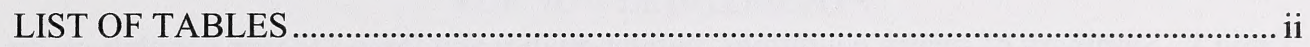

ACKNOWLEDGEMENTS ….......................................................................................

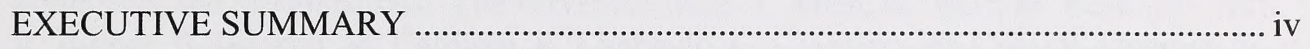

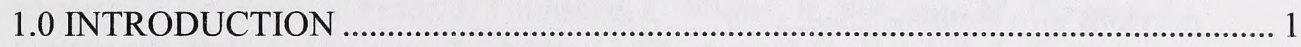

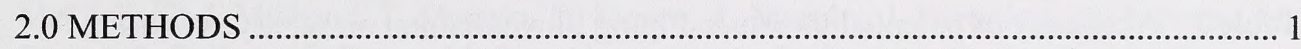

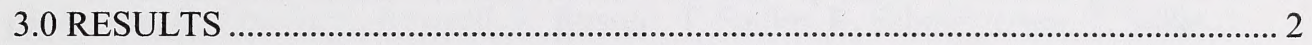

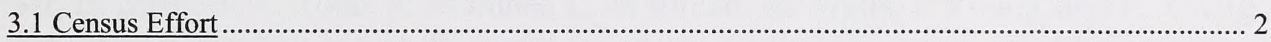

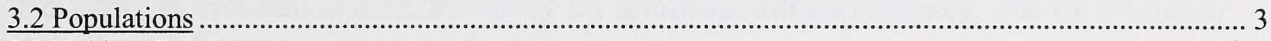

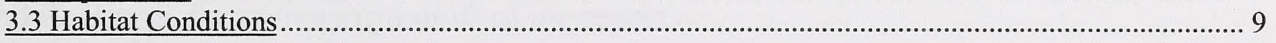

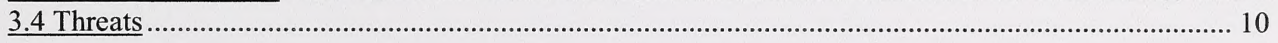

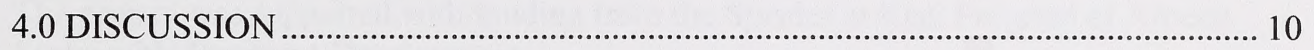

5.0 MANAGEMENT IMPLICATIONS AND FUTURE DIRECTIONS ........................ 12

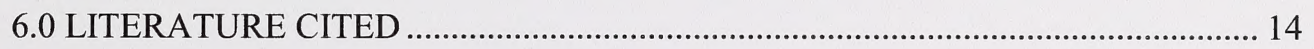




\section{LIST OF TABLES}

Table 1. Summary of survey conditions, habitat quality and Piping Plover populations on 115 lakes surveyed during the 2001 International Piping Plover Census in Alberta. 4

Table 2. Comparison of Piping Plover populations on lakes surveyed in 2001 and on any previous provincial census.................................................

Table 3. Frequency of potential threats to Piping Plover habitat on surveyed lakes in Alberta, and on individual patches of habitat (beaches) identified on surveyed lakes. 


\section{ACKNOWLEDGEMENTS}

The success of the 2001 International Piping Plover Census in Alberta was achieved through the cooperation, dedication, and contributions of a large number of staff, volunteers and organizations. The surveyors were: J. Allen, M. Barr, M. Besko, D. Birn, R. Bjorge, B. Boukall, M. Cardinal, R. Chabaylo, G. Clements, D. Cole, B. Downey, L. Engley, G. Erickson, S. Feser, J. Folinsbee, C. Found, K. Froggatt, M. Gingras, S. Greene, W. Hall, E. Hofman, A. Hubbs, G. Hvengaard, K. Kendell, F. Kunnas, G. McClelland, I. Michaud, T. Morgan, D. Moore, A. Murphy, J. Nicholson, G. Nieman, M. Pearce, R. Pellerin, S. Peters, M. Piorecky, J. Potter, D. Prescott, R. Quinlan, M. Ranger, B. Rippin, C. Rowan, K. Rowsell, R. Russell, T. Sadler, R. Schmelzeisen, T. Sellin, J. Shier, D. Spencer, A. Todd, Z. Waldner, C. Wallman, M. Wells, J. Young, and P. Young. I also thank B. Boukall and M. Piorecky for administrative assistance, and M. Piorecky and R. Bjorge for reviewing a draft of the report.

The project was supported with funding from the Species at Risk Program of Alberta Sustainable Resource Development. 


\section{EXECUTIVE SUMMARY}

The International Piping Plover Census has been conducted across North America every five years since 1991. The 2001 survey was conducted between 3 and 16 June 2001 in Alberta. This report summarizes information on populations and habitats gathered during the census, and compares results to the two previous international censuses and a relatively complete survey conducted in 1986 by Wershler and Wallis (1987).

The 2001 census involved 55 volunteers who expended 586.1 person-hours of effort to survey $917.7 \mathrm{~km}$ of shoreline on 115 Alberta lakes. This greatly exceeded previous survey efforts in the province, but fewer birds were counted than in prior years. A total of 60 pairs and 30 single birds ( 150 individuals) were found on 23 lakes in the province during 2001. This represents a provincial decline of $47.9 \%$ since $1986,16.7 \%$ since 1991, and $45.7 \%$ since 1996. On 38 lakes surveyed during all four censuses, populations have declined $73.7 \%$ since $1986,57.7 \%$ since 1991 , and $63.5 \%$ since 1996 . Forty-two percent of birds were found on three lakes in 2001(West Reflex, Muriel and Plain). The Parkland Region supported the most birds $(91$, or $60.7 \%$ of total) in the province.

Thirty-six lakes were described as having $1^{\circ}$ habitat, with 20 (55.6\%) being occupied by Piping Plovers. Twenty lakes were reported to have, at best, $2^{\circ}$ habitat $(5.0 \%$ were occupied) and 18 lakes contained $3^{\circ}$ habitat (11.1\% occupied). A total of 109 individual patches of $1^{\circ}$ habitat ( $27.5 \%$ occupancy) were identified in the province, as well as 129 patches of $2^{\circ}$ ( $5.4 \%$ occupancy) and 128 of $3^{\circ}$ quality ( $6.3 \%$ occupancy). Cattle grazing was identified as a threat to Piping Plovers on approximately two-thirds of lakes, and over $40 \%$ of individual beaches. Vegetation encroachment, motorized vehicles, and recreational/residential use were also prominent threats to Piping Plover habitat, with water management activities and petroleum extraction/exploration being relatively minor impacts on a provincial scale. In general, the incidence of potential threats was similar to that reported during previous surveys.

The lower populations present during 2001 might be partly attributable to low water levels following three years of below-average precipitation in southern and central Alberta (77.5\% of waterbodies were reported to have lower water levels than in 1996). It is also possible that birds have redistributed to other parts of their breeding range where habitat conditions are more favorable. Assessment of this possibility must await final tabulation of census results from across North America. 


\subsection{INTRODUCTION}

Piping Plover (Charadrius melodus) populations have declined throughout their North American breeding range in recent decades, and the species is listed as "endangered" or "threatened" in most federal, state, and provincial jurisdictions (Goossen et al. 2000). The species was listed as "endangered" by the Committee on the Status of Endangered Wildlife in Canada in 1985, and reaffirmed in 2001 (COSEWIC 2001). The "endangered" designation was assigned in Alberta in 1987 (Prescott 1997), and reaffirmed in 2000 (unpubl. Ministerial Order).

The International Piping Plover Census was established to provide a thorough inventory of Piping Plover populations on both the breeding and wintering grounds every five years. The primary function of the census is to gather data for monitoring population trends that will be used to assess success of recovery efforts in North America (Haig and Plissner 1993). The first breeding census in 1991 found 5482 adult plovers in the U.S, Canada, and the French territory of St. Pierre and Miquelon (Haig and Plissner 1993). The second census in 1996 documented 5913 individuals, a 7.8\% increase since 1991 (Plissner and Haig 1997). Wintering populations in the southern U.S., Mexico and the Caribbean decreased 27\% from 3451 individuals in 1991 (Haig and Plissner 1993) to 2515 in 1996 (Plissner and Haig 1997). Breeding populations in Alberta increased from 180 to 276 individuals between 1991 and 1996, although this increase was at least partly attributable to a large increase in the number of lakes surveyed (48 to 103; Hofman 1994, Bjorge 1997).

The third international census was conducted in 2001. This report documents the 2001 census in Alberta, and compares the results to the two previous international censuses and a relatively complete provincial survey of Piping Plovers in Alberta conducted in 1986 by Wershler and Wallis (1987). Together, these surveys provide an excellent profile of Piping Plover population trends and breeding distribution of Piping Plovers in this province over the past 15 years.

\subsection{METHODS}

The basic goal of the 2001 census in Alberta, and elsewhere, was to survey all breeding habitat known to be either currently or recently suitable for Piping Plovers. Piping Plover habitat is highly dynamic, and regular monitoring of many potential lakes in the province does not occur between international census periods. Therefore, we initially included all lakes surveyed during either the 1991 or 1996 censuses on the list of basins to be surveyed in 2001. However, it was recognized that many potential basins that support plovers in the province have never been identified or surveyed (Bjorge and Murphy in prep, Prescott 2001), and that lakes previously available for breeding might no longer contain suitable habitat. Therefore, aerial reconnaissance of a broad area of central Alberta (the core of the provincial breeding range) was conducted in May 2001 (Prescott 2001). This survey identified 22 previously unsurveyed basins that appeared to have high or medium potential for plovers, and 11 previously surveyed basins that contained no 
apparent breeding habitat ${ }^{1}$. These unsuitable lakes were deleted from the 2001 ground survey, and were assumed to be unpopulated for comparison of populations across censuses. In all, 116 lakes were targeted for ground surveys in 2001.

The survey was coordinated by Alberta Fish and Wildlife Division in the Parkland Region. The coordinator prepared information packages for each lake, including a census form and instructions provided by the International Piping Plover Coordinating Group, a map of the lake, and a form to document individual habitats and associated threats (if any) on each lake surveyed. The coordinator then assigned staff or volunteers to survey specific lakes. Whenever possible, lakes were surveyed by the same observer(s) who conducted surveys on previous censuses. Participants unfamiliar with field identification of Piping Plovers or their habitats were paired with more experienced observers, or were invited to observe plovers on lakes known to be occupied before conducting surveys on their assigned lakes.

Methodology for the field survey was established by the International Piping Plover Coordinating Group, and was little changed from previous surveys (see Plissner and Haig 1997). In brief, observers throughout North America walked shorelines of all lakes while counting single or paired Piping Plovers, and were asked to record information such as weather conditions, types of habitats surveyed and occupied by plovers, distance traveled, and percentage of shoreline not surveyed. Observers in Alberta were also asked to collect supplementary data considered important for the management of Piping Plovers in this province. This information included identifying discrete stretches of shoreline on each lake that contained (in their opinion) either $1^{\circ}, 2^{\circ}$, or $3^{\circ}$ habitat, specific threats to these shorelines, and the presence of California (Larus californicus) or Ring-billed Gull ( $\underline{\mathrm{L}}$. delawarensis) colonies, as these birds are known predators of Piping Plover nests and chicks (Whyte 1985). Observers were advised not to spend time looking for nests, but were asked to inspect all birds for the presence of color bands. The survey period throughout North America was set between 3 and 16 June.

\subsection{RESULTS}

\section{$\underline{3.1 \text { Census Effort }}$}

A total of 115 lakes were surveyed during the 2001 census (Table 1). Only two lakes that were surveyed in either 1991 or 1996 could not be visited in 2001: Lesser Slave Lake and Neutral Hills C2 (also missed in 1996). One new lake targeted for survey (Island Lake) was not checked in 2001. Two lakes were opportunistically added to the survey (Chain Lake \#2 and Sittingstone Lake). At least 107 lakes (93\% of total) were surveyed during the recommended survey period of 3-16 June (survey date was not reported for one lake). The earliest surveys were conducted on 1 June (two lakes), with all but one survey being

\footnotetext{
${ }^{1}$ Lakes surveyed in previous years that were not targeted for ground surveys in 2001 were Bunder, Floatingstone, Joseph, Brosseau, St. Cyr, Eliza, Lonepine, Majors, Oliver, Sounding and Wilkins. These lakes were determined from aerial surveys in May 2001 to be unsuitable for Piping Plovers.
} 
completed by 21 June. Long Lake, in the Parkland Region, was surveyed well outside the recommended survey window (1 July; Table 1).

Fifty-five observers participated in the surveys (see Acknowledgements), contributing an estimated 586.1 person-hours of survey effort (excluding preparation and travel time). These observers covered at least $917.7 \mathrm{~km}$ of shoreline by foot, boat or all-terrain vehicle (Table 1). These values are minimum estimates, as person-hours and distance surveyed were not recorded for one and two lakes, respectively. Furthermore, time and distance were sometimes recorded as " 0 " when a lake was visited and habitat was immediately assessed to be unsuitable and unpopulated by plovers. The percentage of habitat not surveyed on particular lakes varied from 0 to $95 \%$ (mean=10.9\%, $n=110$ lakes). However, these values are misleading, as some observers based estimates on total shoreline, whereas others based estimates on the length of suitable habitat. Therefore, the percentage of total shoreline missed on surveyed lakes was certainly higher than $10.9 \%$, but the percentage of suitable habitat missed was much less (likely $<5 \%$ ).

The overall level of effort was substantially higher in 2001 than in 1991 (17 participants surveyed $166.7 \mathrm{~km}$ of shoreline on 48 lakes [Hofman 1994]) and 1996 (59 participants surveyed $751.8 \mathrm{~km}$ of shoreline on 103 lakes [Bjorge 1997]).

\section{$\underline{3.2}$ Populations}

A total of 150 birds ( 60 pairs, 30 singles) were found on 23 lakes during the 2001 census (Table 1). Forty-two percent of the birds were found on three lakes, with the highest number being found on the Alberta side of West Reflex Lake (31; an additional 18 birds were counted on the Saskatchewan side and are not included in this report). Only two lakes besides West Reflex had more than nine birds (19 on Muriel Lake, 13 on Plain Lake). In addition to Plain Lake, three previously unsurveyed lakes were found to support Piping Plovers (six on Hansman Lake, five on an unnamed lake SE of Capt. Eyre Lake, and three on Frog Lake). The Parkland Region supported most of the provincial population of Piping Plovers (91 birds [60.7\% of total] on 13 lakes), followed by the Bow Region (35 birds [23.3\%] on seven lakes), and the Northeast Boreal Region (22 birds [14.7\%] on two lakes. Only one lake in the Prairie Region (St. Mary Reservoir) supported Piping Plovers (total of two birds [1.3\%]).

Populations in 2001 were well below those counted on the previous surveys. Total numbers have declined $47.9 \%$ from $288+$ individuals on 28 lakes counted in 1986, $16.7 \%$ from 180 birds on 26 lakes in 1991, and 45.7\% from 276 birds on 31 lakes in 1996 (Wershler and Wallis 1987, Hofman 1994, Bjorge 1997). Of 59 lakes surveyed in both 1986 and 2001 (including lakes not actually surveyed, but presumed to be unpopulated from knowledge of habitat conditions), 27 have declined in population, 24 remained unchanged (all were 0 in both years) and eight have increased (Baxter, Chain \#1, Hansman, Killarney, Leane, Plover, Red Deer and Sunken lakes). Forty-four lakes were surveyed in both 1991 and 2001, with 21 decreasing, 20 remaining the same (18 of these were 0 in both years), and three increasing (Baxter, Chain \#1 and West Reflex lakes). Since 1996 ( $n=103$ lakes), 25 have decreased, 68 remained the same (all were 0 
00000040

o doogho

0000

00000000

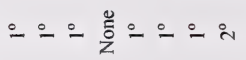

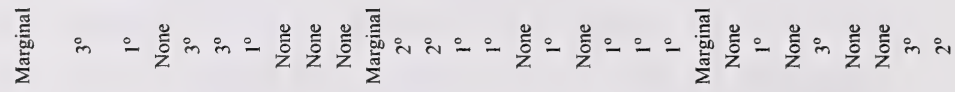

言章 $z>>z z>>z$

z

$>z z z z z z z z z>z z z z z>z z z z>>z z \quad z z$

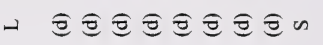

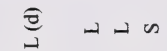

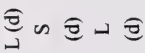

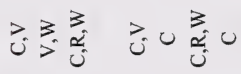

$-\quad 0 \frac{0}{0}>>$

$>0>>$

$\approx \vec{x}>\overrightarrow{0} 0$

$\sum_{i}^{3}$ uेंu

ن

00001000

0000

$$
\circ \circ
$$

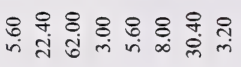

กิ $8: \%$

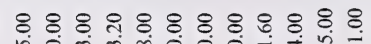

\&

m

군

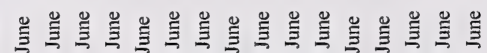

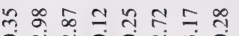

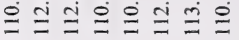

กิ ซำ

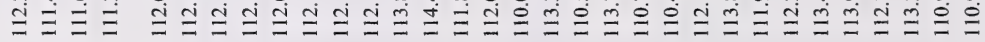

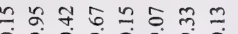

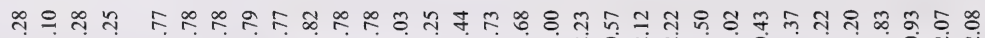

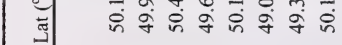
in $\bar{n}$ i

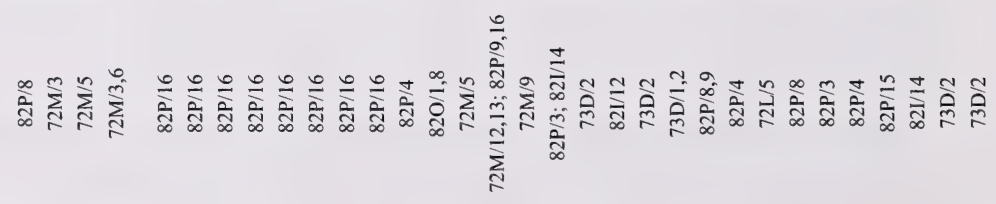

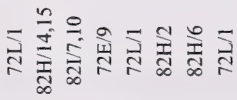
की 


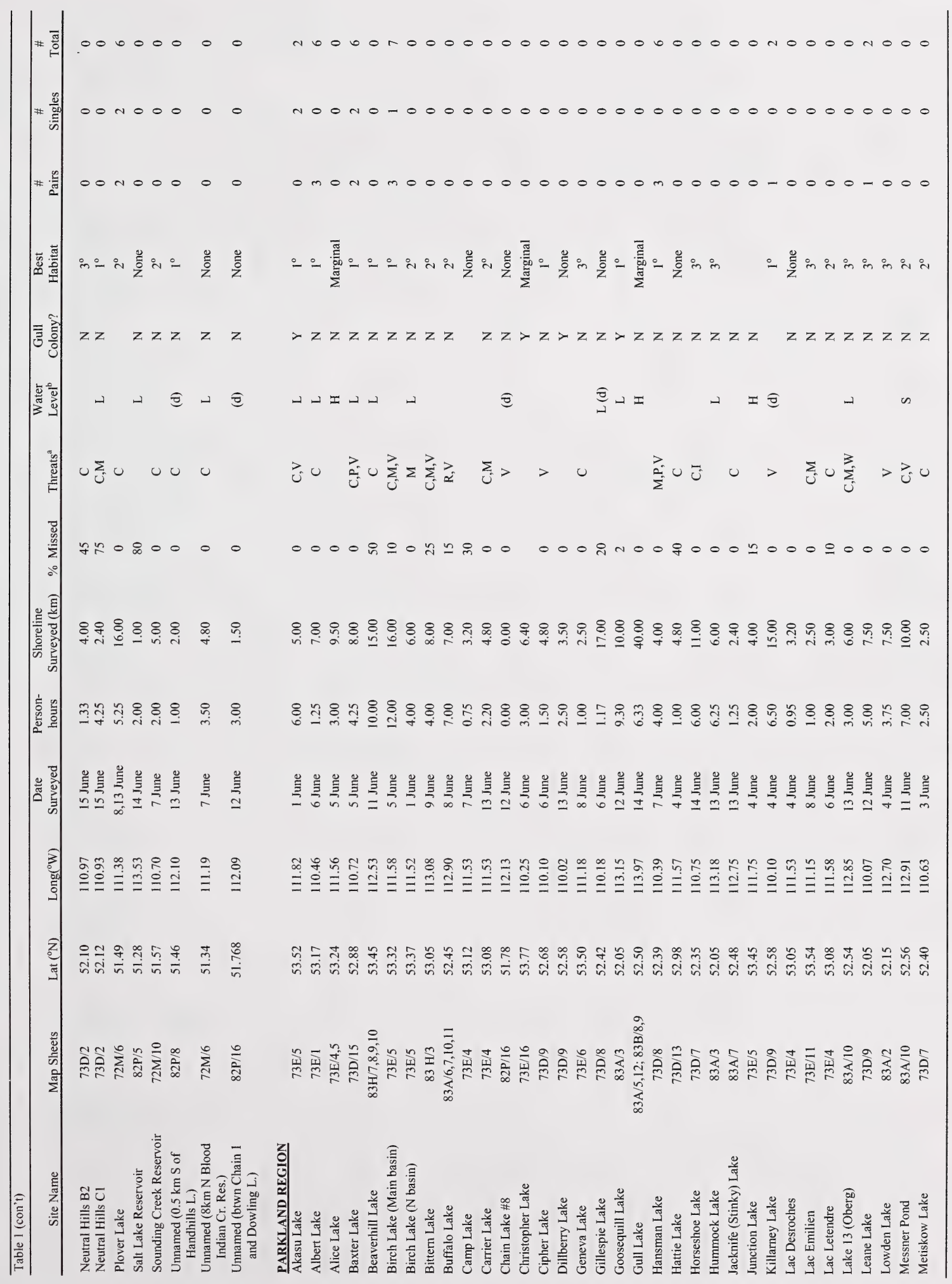




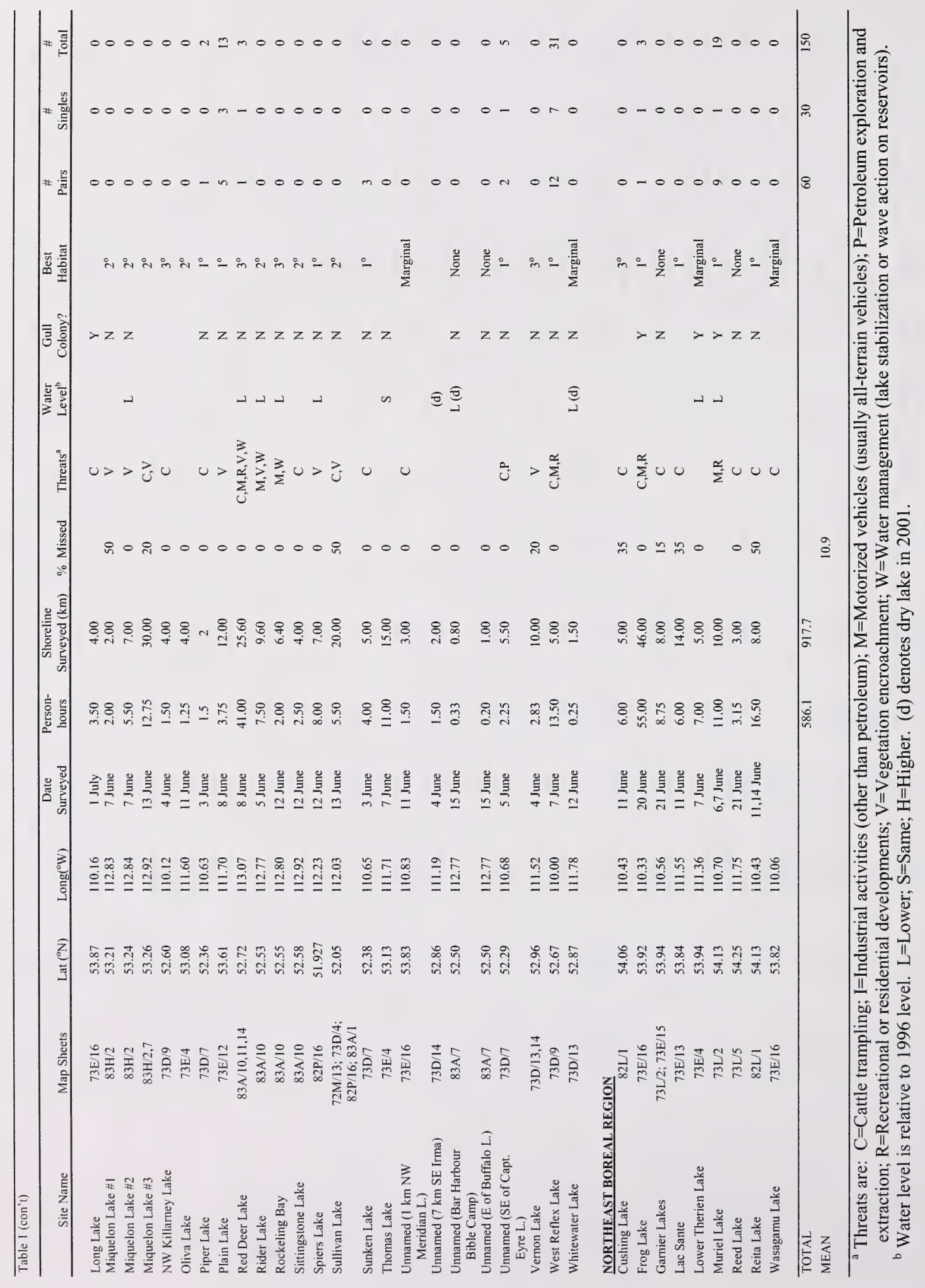


Table 2. Comparison of Piping Plover populations on lakes surveyed in 2001 and on any previous provincial census.

Total \# birds

\begin{tabular}{cccc}
\hline $1986^{\mathrm{a}}$ & 1991 & 1996 & 2001 \\
\hline \multirow{3}{*}{17} & 2 & & \\
& 3 & 1 & 0 \\
& & 1 & 0 \\
& & 0 & 0 \\
& 4 & 0 & 0 \\
& & 2 & 0 \\
1 & & 0 & 0 \\
& & 3 & 2 \\
& & 0 & 0
\end{tabular}

PRAIRIE REGION

Chappice Lake

Keho Lake

McGregor Lake

Reesor Lake

Sam Lake

Shanks Lake

St. Mary Reservoir

Unnamed (SE of Sam L.)

\section{BOW REGION}

Antelope Lakes

Chain Lake \#1 (Pearl Lake)

Chain Lake \#2

Chain Lake \#3 (Clear Lake)

Chain Lake \#3A

Chain Lake \#4

Chain Lake \#5

Chain Lake \#6

Chain Lake \#7

Chestermere Lake

Cochrane Lake

Dowling Lake

Dragon Lake

Eagle Lake

Foster Lake

Frank Lake

Gooseberry Lake

Greenlee Lake

Handhills Lake

Janet Lake

Lake Newell

Little Fish Lake

Long Lake ${ }^{c}$

Majors Lake

McDonald Lake

Mudspring Lake

Namaka Lake

Neutral Hills A

Neutral Hills B1

Neutral Hills B2

Neutral Hills C1

Plover Lake

Salt Lake Reservoir

Sounding Lake

\section{PARKLAND REGION}

Akasu Lake

Albert Lake

Alice Lake

Baxter Lake

Beaverhill Lake

Birch Lake (Main basin)

Birch Lake (N basin)

Bittern Lake

Buffalo Lake

Camp Lake

Carrier Lake

Chain Lake \#8

Christopher Lake

(0)
Numerical change

1986-2001 1991-2001

1996-2001

$\begin{array}{ccc}-17 & -2 & -1 \\ & -3 & -1 \\ & & 0 \\ & & 0 \\ -6 & -4 & -2 \\ & & 0 \\ & & -1 \\ -1 & & 0\end{array}$

\begin{tabular}{|c|c|c|}
\hline c & \multirow[t]{2}{*}{2} & \multirow[t]{2}{*}{4} \\
\hline 0 & & \\
\hline-1 & -2 & 0 \\
\hline 0 & 0 & 0 \\
\hline-7 & 0 & -8 \\
\hline 0 & & 0 \\
\hline-1 & -2 & 0 \\
\hline 0 & 0 & 0 \\
\hline & & 0 \\
\hline-12 & -17 & -50 \\
\hline 0 & & \\
\hline 0 & & 0 \\
\hline-2 & & 2 \\
\hline 0 & & 0 \\
\hline-4 & -9 & 0 \\
\hline-3 & -4 & -2 \\
\hline-28 & -11 & -45 \\
\hline-3 & -1 & 0 \\
\hline-20 & -16 & 3 \\
\hline-1 & & 0 \\
\hline 0 & 0 & 0 \\
\hline 0 & & $\begin{array}{l}0 \\
0\end{array}$ \\
\hline-12 & -2 & 0 \\
\hline-4 & 0 & -2 \\
\hline 0 & 0 & 0 \\
\hline-6 & -5 & -5 \\
\hline 6 & & 6 \\
\hline-18 & -18 & -16 \\
\hline
\end{tabular}

$-18$

\begin{tabular}{|c|c|c|c|c|c|c|}
\hline & & 10 & 2 & & & -8 \\
\hline & & 2 & 6 & & & 4 \\
\hline & & 0 & 0 & & & 0 \\
\hline 0 & 2 & 2 & 6 & 6 & 4 & 4 \\
\hline 0 & & 13 & 0 & 0 & & -13 \\
\hline & & 14 & 7 & & & -7 \\
\hline & & 5 & 0 & & & . \\
\hline 0 & & 2 & 0 & 0 & & -2 \\
\hline 2 & 0 & 0 & 0 & -2 & 0 & 0 \\
\hline & & 0 & 0 & & & 0 \\
\hline & & 0 & 0 & & & 0 \\
\hline & 0 & 0 & 0 & & 0 & 0 \\
\hline & & 0 & 0 & & & 0 \\
\hline
\end{tabular}




\begin{tabular}{|c|c|c|c|c|c|c|c|}
\hline \multirow[b]{2}{*}{ Lake } & \multicolumn{4}{|c|}{ Total \# birds } & \multicolumn{3}{|c|}{ Numerical change } \\
\hline & $1986^{\mathrm{a}}$ & 1991 & 1996 & $2001^{\mathrm{a}}$ & 1986-2001 & 1991-2001 & 1996-2001 \\
\hline Cipher Lake & 4 & 4 & 4 & 0 & -4 & -4 & -4 \\
\hline Dillberry Lake & 0 & & 0 & 0 & 0 & & 0 \\
\hline Gillespie Lake & 0 & 0 & 0 & 0 & 0 & 0 & 0 \\
\hline Goosequill Lake & 2 & 0 & 0 & 0 & -2 & 0 & 0 \\
\hline Gull Lake & 0 & & 0 & 0 & & & 0 \\
\hline Hansman Lake & 0 & & & 6 & 6 & . & \\
\hline Hattie Lake & (0) & & 0 & 0 & 0 & & 0 \\
\hline Horseshoe Lake & 2 & 0 & 6 & 0 & -2 & 0 & -6 \\
\hline Hummock Lake & & & 0 & 0 & & & 0 \\
\hline Jacknife (Stinky) Lake & & 0 & 0 & 0 & & 0 & 0 \\
\hline Joseph Lake & & & 0 & (0) & & & 0 \\
\hline Junction Lake & & & 2 & 0 & & & -2 \\
\hline Killarney Lake & 0 & 22 & 23 & 2 & 2 & -20 & -21 \\
\hline Lac Desroches & & & 0 & 0 & & & 0 \\
\hline Lac Letendre & & & 0 & 0 & & & 0 \\
\hline Lake 13 (Oberg) & 0 & & 0 & 0 & 0 & & 0 \\
\hline Leane Lake & 0 & 2 & 1 & 2 & 2 & 0 & 1 \\
\hline Lonepine Lake & 0 & 0 & 0 & (0) & 0 & 0 & 0 \\
\hline Lowden Lake & 0 & 0 & 0 & 0 & 0 & 0 & 0 \\
\hline Messner Pond & & 0 & 0 & 0 & & 0 & 0 \\
\hline Metiskow Lake & & 2 & 2 & 0 & & -2 & -2 \\
\hline Miquelon Lake \#1 & & & 1 & 0 & & & -1 \\
\hline Miquelon Lake \#2 & 0 & 0 & 0 & 0 & 0 & 0 & 0 \\
\hline Miquelon Lake \#3 & & 0 & 0 & 0 & & 0 & 0 \\
\hline N.W. Killarney Lake & & & 2 & 0 & & & -2 \\
\hline Oliva Lake & & & 0 & 0 & & 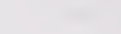 & 0 \\
\hline Oliver Lake & 0 & & 0 & (0) & & & 0 \\
\hline Piper Lake & $15+$ & 12 & 6 & 2 & -13 & -10 & -4 \\
\hline Red Deer Lake & (0) & & 2 & 3 & 3 & & I \\
\hline Rider Lake & 15 & 7 & 0 & 0 & -15 & -7 & 0 \\
\hline Rockeling Bay & 18 & 6 & 0 & 0 & -18 & -6 & 0 \\
\hline Spiers Lake & 6 & 2 & 0 & 0 & -6 & -2 & 0 \\
\hline Sullivan Lake & 0 & & 0 & 0 & 0 & & 0 \\
\hline Sunken Lake & $5+$ & 8 & 7 & 6 & 1 & -2 & -1 \\
\hline Thomas Lake & & & 0 & 0 & & & 0 \\
\hline Unnamed (7 km SE Irma) & & & 0 & 0 & & & 0 \\
\hline Unnamed (Bar Harbour Bible Camp) & & & 0 & 0 & & & 0 \\
\hline Unnamed ( $E$ of Buffalo L.) & & & 0 & 0 & & & 0 \\
\hline Vernon Lake & (0) & & 0 & 0 & 0 & & 0 \\
\hline West Reflex Lake ${ }^{d}$ & $46+$ & 12 & 19 & 31 & -15 & 19 & 12 \\
\hline Whitewater Lake & & & 0 & 0 & & & 0 \\
\hline Wilkins Lake & & & 0 & (0) & & & 0 \\
\hline \multicolumn{8}{|l|}{ NORTHEAST BOREAL REGION } \\
\hline Bunder Lake & & & 0 & (0) & & & 0 \\
\hline Floatingstone Lake & & & 0 & (0) & & & 0 \\
\hline Garnier Lakes & & & 0 & 0 & & & 0 \\
\hline Lac Brosseau & & & 0 & (0) & & & 0 \\
\hline Lac St. Cyr & & & 0 & (0) & & & 0 \\
\hline Lake Eliza & & & 0 & (0) & & & 0 \\
\hline Lower Therien Lake & & & 0 & 0 & & & 0 \\
\hline Muriel Lake & & & 17 & 19 & & & 2 \\
\hline Reed Lake & & & 0 & 0 & & & 0 \\
\hline Reita Lake & & & & 0 & & & \\
\hline Wasagamu Lake & & & & 0 & & & \\
\hline
\end{tabular}

${ }^{a}(0)$ indicates that lake not surveyed from the ground, but populations assumed to be 0 because of lack of suitable habitat (Wershler and Wallis 1987, Prescott 2001).

${ }^{\mathrm{b}}$ Foster Lake referred to as "Unnamed lake north of Sounding Lake (31-37-W4)" by Wershler and Wallis (1987).

${ }^{\mathrm{c}}$ Long Lake referred to as "Large pond east of Bruce Lake (9-26-25-W4)" by Wershler and Wallis (1987).

${ }^{\mathrm{d}}$ Numbers are for Alberta side of West Reflex Lake only. 
in both years) and 10 have increased (Albert, Baxter, Chain \#1, Foster, Leane, Little Fish, Muriel, Plover, Red Deer, and West Reflex lakes; Table 2).

Thirty-eight lakes have been surveyed in all five-year intervals since 1986 (including lakes presumed to be unpopulated in either 1986 or 2001). Populations on these lakes in 2001 (74 birds) have declined $73.7 \%$ since 1986 (281+ birds), 57.7\% since 1991 (175 birds) and 63.5\% since 1996 (203 birds). Six lakes (Chain \#4, Dowling, Handhills, Piper, Sunken and West Reflex) have supported Piping Plovers in all years, whereas eight (Chain \#3A and 7, Gillespie, Lonepine, Lowden, McDonald, Miquelon \#2, and Neutral Hills B2) have never supported any birds. Nineteen lakes that had birds in 1986 are now unpopulated, and only four lakes that were unpopulated in 1986 have supported birds on any subsequent survey (Baxter, Chain \#1, Leane and Killarney). Only West Reflex Lake has maintained substantial populations (range of 12 in 1991 to 46+ in 1986) over all four surveys (Table 2).

A total of 15 color-banded birds were observed on six Alberta lakes (excluding the Saskatchewan side of West Reflex Lake, where three additional birds were encountered) during the 2001 census. Five birds (three on West Reflex, two on Handhills) were adults banded on the same lakes earlier in the season. One bird on Akasu Lake had been banded as a chick on Chain Lake \#4 in 1999, and one bird on West Reflex Lake was a chick banded on Sunken Lake in 1999. The origin of six birds (two on Plain, one on Albert, three on West Reflex) could not be determined, as one or more color bands were missing. However, four or these birds were known to have been banded on one of five lakes in Alberta in 1998. The only encounter of a foreign bird was an adult on Chain \#4, which matched the description of a bird banded on the wintering grounds in Texas during the late 1990s (to be confirmed). The number (if any) of birds banded in Alberta between 1995 and 2000 (unpubl. data) that were sighted outside of the province during the 2001 census is not known at the time of writing. A more complete analysis of band returns from birds banded in Alberta is currently being prepared.

\section{$\underline{3.3 \text { Habitat Conditions }}$}

Habitat conditions $\left(1^{\circ}, 2^{\circ}, 3^{\circ}\right.$ or none) were recorded for 98 lakes, with an additional 10 lakes described as having "marginal" habitat being omitted from further analysis (it is unclear whether these should be classified as $3^{\circ}$ or "none"). Thirty-six lakes had $1^{\circ}$ habitat of which $20(55.6 \%)$ were occupied. Twenty lakes had, at best, $2^{\circ}$ habitat, of which one (5.0\%) was occupied (Plover Lake). An additional 18 lakes had no better than $3^{\circ}$ habitat, of which two (11.1\%) were occupied (Leane and Red Deer lakes). Twenty-four lakes, all unoccupied, were described as having no habitat in 2001 (Table 1). In all, observers identified 109 patches of $1^{\circ}$ habitat on 36 lakes, of which 30 patches $(27.5 \%)$ on 19 lakes were occupied by Piping Plovers. One hundred and twenty-nine patches of $2^{\circ}$ habitat were identified on 47 lakes, of which seven patches $(5.4 \%)$ on seven lakes were occupied. Tertiary habitats $(\mathrm{n}=128)$ were found on 53 lakes, with eight patches $(6.3 \%)$ being occupied on five lakes.

Assessment of changes in water level since 1996 were provided for 40 lakes, with 31 (77.5\%) being lower, four (10.0\%) being higher, and five (12.5\%) being similar (Table 1). 
Observers reported 20 lakes to be dry (Table 1), and numerous others as being at very low levels. Four dry lakes supported birds in 2001 (Chain \#1 and \#4, Dowling and Killarney).

\section{$\underline{3.4 \text { Threats }}$}

Potential threats to nesting beaches were reported for 86 lakes, and for 365 separate stretches of $1^{\circ}, 2^{\circ}$, or $3^{\circ}$ habitat on these lakes. On lakes, or habitats within lakes where no threats were identified, it was usually not obvious whether no threats were present, or whether they were not reported. Nevertheless, the available reports likely represent a reasonable cross-section of impacts on Piping Plover habitat in Alberta.

Cattle grazing was the greatest potential threat to Piping Plovers lakes, being recorded on $66.3 \%$ of all lakes surveyed and $69.6 \%$ of occupied lakes (Table 3 ). Grazing was also the most frequently observed threat to individual beaches $(47.9 \%$ of total, $40.0 \%$ of occupied beaches). Vegetation encroachment, a result of declining water levels, was the second most prevalent impact on Piping Plover habitat (41.9\% of all lakes, $52.2 \%$ of occupied lakes, and approximately $26 \%$ of individual beaches). Motorized vehicles ( $18.6 \%$ of all lakes, $34.8 \%$ of occupied lakes) and recreational/residential use (12.8\% of all lakes, $26.1 \%$ of occupied lakes) were also prominent threats on lakes, but much less so on individual beaches $(<9 \%)$. Water management activities and petroleum extraction/exploration were relatively minor threats to most lakes $(\leq 13 \%)$ and habitats $(\leq 6 \%$; Table 3$)$. The presence/absence of Ringbilled or California Gull colonies was noted on 100 lakes, with $17(17.0 \%)$ having active colonies. Piping Plovers occupied five of these lakes in 2001 (Akasu, Little Fish, Frog and Muriel lakes, and St. Mary Reservoir).

The high incidence of grazing (69.6\%) and motorized vehicles (34.8\%) on occupied lakes is consistent with levels reported in both $1991(66.7 \%$ and $25.9 \%$, respectively [recalculated from Hofman 1994]) and 1996 (82.6\% and 17.4\% [Bjorge and Murphy in prep.]). The incidence of vegetation encroachment was not reported in 1991, but was cited as $74.1 \%$ in 1996 (Bjorge and Murphy in prep.).

\subsection{DISCUSSION}

There have been four major surveys of Piping Plovers conducted in Alberta over the past 15 years, as well as annual research and population monitoring at key breeding areas in the province over the past decade (e.g. Hofman 1993, Heckbert 1994, Heckbert and Cantelon 1996, Richardson 1999, Michaud and Prescott 1999, Engley and Michaud 2000). These initiatives have steadily increased our understanding of the distribution of Piping Plovers and their habitat in Alberta, and resulted in an increasingly skilled group of observers in the province. Consequently, the 2001 survey achieved the most complete and comprehensive count of Piping Plovers ever conducted in the province. Despite this effort, populations of Piping Plovers in Alberta are at their lowest level ever recorded. The 150 individuals counted in 2001 is nearly a 50\% reduction from overall populations found in 1986 and 1996. Had the survey effort expended in 2001 been achieved on previous censuses, the percentage decline would undoubtedly have been much more dramatic. 


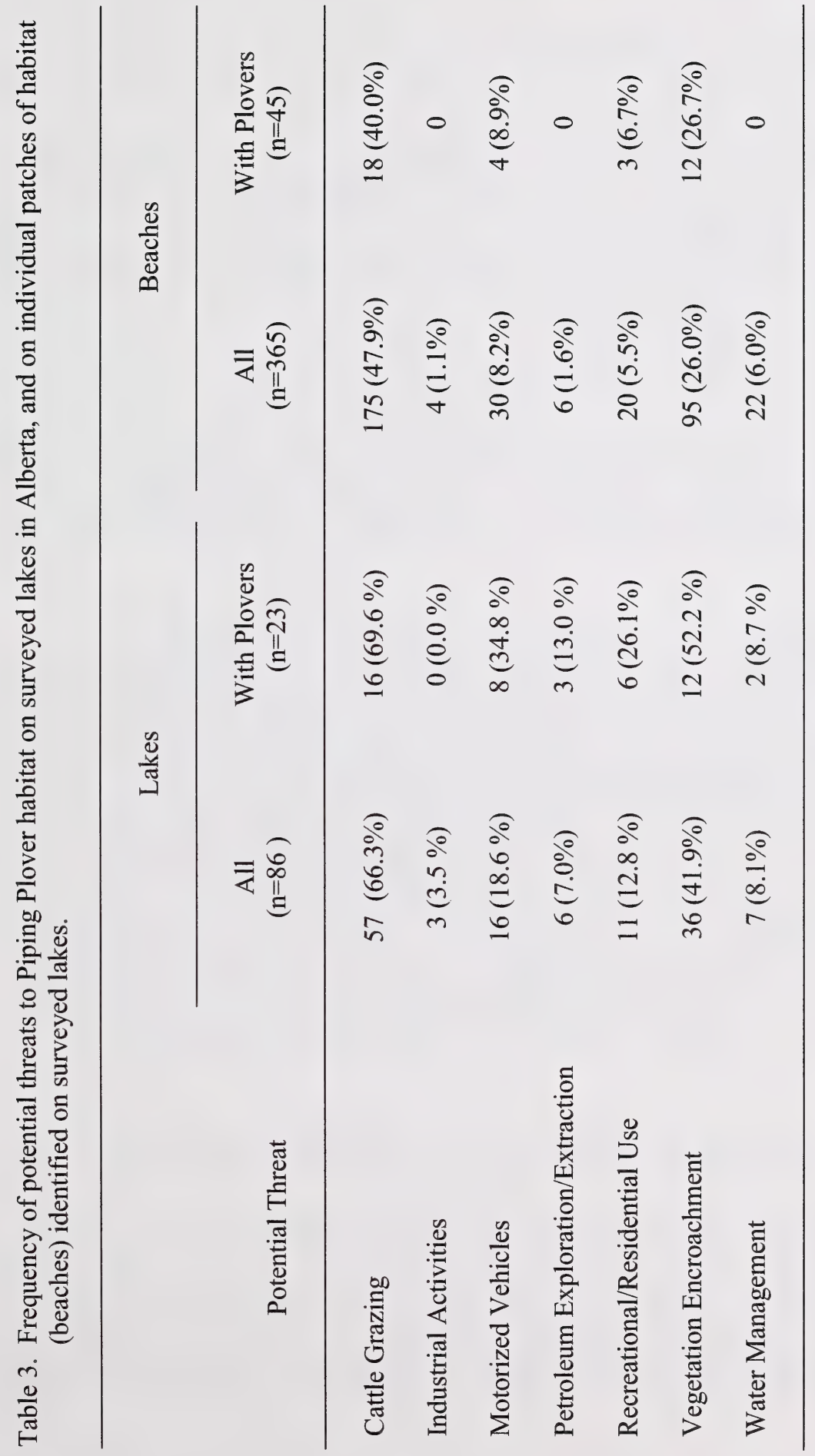


The reasons for the declining populations in Alberta are not clear. In 2001, central and southern Alberta was in its third year of below-average precipitation (data from Alberta Agriculture, Food and Rural Development 2001). As a result, over $75 \%$ of Piping Plover lakes were reported to be lower in 2001 than in 1996, and 20 of those surveyed were dry. Although receding water levels are necessary to expose Piping Plover habitat (Prescott 1997), prolonged low water levels cause beaches to become vegetated and unsuitable for nesting. However, the percentage of occupied lakes impacted by vegetation encroachment was actually lower in $2001(52.2 \%)$ than it was in 1996 (74.1\%; Bjorge and Murphy in prep.). Furthermore, almost half of all lakes with $1^{\circ}$ habitat, and almost three-quarters of all beaches of $1^{\circ}$ quality, were unoccupied in 2001 . This strongly suggests that much suitable habitat was unoccupied in the province in 2001, and that provincial declines in population size cannot be explained by recent deterioration of habitat quality. Given that the availability of Piping Plover habitat varies from year to year across the species' range, it is also possible that birds that normally breed in Alberta nested elsewhere in 2001. Preliminary data from the International Census (C. Ferland, pers. comm.) suggest that populations are well below 1996 levels across the Canadian prairies and much of the Northern Great Plains, but substantially higher along the Missouri River. Population declines on the Canadian prairies could therefore reflect a short-term redistribution of birds to areas further south. Assessment of this suggestion will not be possible until final results of the continental survey are available in early 2002 (C. Ferland, pers. comm.).

As in all previous surveys, the 2001 total of 150 birds is likely an underestimate. There undoubtedly remain a number of lakes in the province that have not yet been surveyed, and which could support populations of breeding birds. For example, incidental observations of Piping Plovers were reported from two lakes not included in the 2001 census: Stirling Lake (south of Lethbridge) on 21 May (Horch 2001), and Whitford Lake (northeast of Lamont) on 15 June (R. Hughes, pers. comm.). Furthermore, single birds were reported from Gull Lake on 12 or 13 May (J. Rogers, pers. comm.), and from Beaverhill Lake on 24 May (D. Dekker, pers. comm.). These lakes were included in the 2001 survey, but no birds were found during the official census period. It is possible that most or all of these birds were transients, but breeding at some sites cannot be completely ruled out. Total numbers were also likely to be underestimated because observers were specifically discouraged from searching for nests. Thus, many of the 30 single birds encountered during the survey could have been members of a breeding pair, which would substantially increase the calculated provincial populations. However, given the standardized methodology used on all international censuses, it is unlikely that the precision of the 2001 population estimate was any different than in previous years.

\subsection{MANAGEMENT IMPLICATIONS AND FUTURE DIRECTIONS}

The Piping Plover has recently been confirmed as an endangered species in Alberta, and a recovery team and detailed management plan will be assembled by early 2002. The 2001 survey therefore provides wildlife managers with important and contemporary information on distribution of birds and habitat, and anthropogenic threats that must be managed if sustainable populations are to persist in Alberta. A key element of management efforts will be ongoing surveys in the province. These surveys are critical for monitoring population trends, tracking habitat suitability, and determining 
the success of management initiatives. The following recommendations to improve census effectiveness are offered:

1. Continue participation in the five-year survey, but continue monitoring a subset of key lakes on an annual basis

2. Eliminate lakes from the survey that have never supported Piping Plovers, and which appear to have no possibility of supporting plovers in the future

3. Continue to search for new water bodies that have never been surveyed, but which could support plovers. Four such lakes were identified during the 2001 aerial survey and subsequent ground surveys

4. Continue to improve observation skills of observers through regular training and participation in ongoing Piping Plover research and management

5. When possible, breeding surveys should be followed by brood surveys to monitor productivity on lakes in Alberta. 


\subsection{LITERATURE CITED}

Alberta Agriculture, Food and Rural Development. 2001. Alberta agricultural weather summary. http://www.agric.gov.ab.ca/navigation/sustain/climate/index.html.

Bjorge, R. 1997. The 1996 International Piping Plover Census in Alberta. Pp. 158-163 in 1996 International Piping Plover Census (J. H. Plissner and S. M. Haig, eds.). U. S. Geological Survey-Biological Resources Division, Corvallis, OR. 231 pp.

Bjorge, R. R., and A. J. Murphy. In prep. The 1996 Piping Plover census in Alberta. Alberta Environmental Protection, Natural Resources Service, Red Deer, AB.

COSEWIC. 2001. Canadian species at risk, May 2001. Committee on the Status of Endangered Wildlife in Canada, Ottawa, ON. 31 pp.

Engley, L., and I. Michaud. 2000. Use of predator exclosures to protect Piping Plover nests in Alberta and Saskatchewan. 2000 field season report. Alberta Conservation Association, Edmonton, $\mathrm{AB} 18 \mathrm{pp}$.

Goossen, J. P., S. M. Westworth, B. Yee, D. Thorson, and I. Michaud. 2000. Atlas of Piping Plovers in the Canadian prairie provinces and Ontario. Environment Canada, Edmonton, AB and Regina, SK (multimedia CD-ROM).

Haig, S.M., and J. H. Plissner. 1993. Distribution and abundance of Piping Plovers: results and implications of the 1991 international census. Condor 95: 145-156.

Heckbert, M. D. 1994. Piping Plover (Charadrius melodus) ecology and conservation in Alberta (1994): Reflex and Killarney Lake field report. Unpubl. report, Alberta Fish and Wildlife Service, Vermilion, AB. 152 pp.

Heckbert, M. D., and K. D. Cantelon. 1996. Piping Plover (Charadrius melodus) ecology and conservation in Alberta (1995): east-central Alberta field report. Unpubl. report, Alberta Fish and Wildlife Service, Vermilion, AB. 163 pp.

Hofman, D. E. 1993. 1993 Piping Plover survey, Little Fish Lake, Alberta. Unpubl. report, Alberta Fish and Wildlife Division, Red Deer, AB. 8 pp.

Hofman, D. E. 1994. The 1991 Piping Plover census in Alberta. Pp. 43-47 in The 1991 International Piping Plover Census in Canada (S. P. Flemming, ed.). Can. Wildl. Serv. Occas. Paper No. 82. 59 pp.

Horch, P. 2001. Exciting sightings. Sagebrush Chronicle 12:8

Michaud, I., and D. Prescott. 1999. Use of predator exclosures to protect Piping Plover nests in Alberta and Saskatchewan: 1999 field season report. Alberta Conservation Association, Edmonton, AB. 20 pp. 
Plissner, J. H., and S. M. Haig. 1997. 1996 International Piping Plover Census. U. S. Geological Survey-Biological Resources Division, Corvallis, OR. 231 pp.

Prescott, D. R. C. 1997. Status of the Piping Plover (Charadrius melodus) in Alberta. Alberta Wildlife Status Report Series No.1. Alberta Environmental Protection, Edmonton, AB. 19 pp.

Prescott, D. R. C. 2001. Aerial reconnaissance surveys for Piping Plover habitat in east-central Alberta, May 2001. Alberta Sustainable Resource Development, Fish and Wildlife Division, Alberta Species at Risk Report No. 26, Edmonton, AB.

Richardson, I. M. 1999. Predator exclosures: a management technique to increase Piping Plover reproductive success in the Canadian prairies. M.Sc. thesis, University of Alberta, Edmonton, AB. 65 pp.

Wershler, C. R., and C. Wallis. 1987. Status of the Piping Plover in Alberta, 1986. Unpubl. report for World Wildlife Fund Canada and Canadian Wildlife Service, Calgary, AB. 54 pp.

Whyte, A. J. 1985. Breeding ecology of the Piping Plover (Charadrius melodus) in central Saskatchewan. M.Sc. thesis, University of Saskatchewan, Regina, SK. 153 pp. 



\section{List of Titles in This Series}

(as of November 2001)

No. 1 Alberta species at risk program and projects 2000-2001, by Alberta Sustainable Resource Development, Fish and Wildlife Division. (2001)

No. 2 Survey of the peregrine falcon (Falco peregrinus anatum) in Alberta, by R. Corrigan. (2001)

No. 3 Distribution and relative abundance of the shortjaw cisco (Coregonus zenithicus) in Alberta, by M. Steinhilber and L. Rhude. (2001)

No. 4 Survey of the bats of central and northwestern Alberta, by M.J. Vonhof and D. Hobson. (2001)

No. 52000 survey of the Trumpeter Swan (Cygnus buccinator) in Alberta, by M.L. James and A. James. (2001)

No. 6 2000/2001 Brassy Minnow inventory at Musreau Lake and outlet, by T. Ripley. (2001)

No. 7 Colonial nesting waterbird survey in the Northwest Boreal Region - 2000, by M. Hanneman and M. Heckbert. (2001)

No. 8 Burrowing owl trend block survey and monitoring - Brooks and Hanna areas, by D. Scobie and R. Russell. (2000)

No. 9 Survey of the Lake Sturgeon (Acipenser fulvescens) fishery on the South Saskatchewan River, Alberta (JuneSeptember, 2000), by L.A. Winkel. (2000)

No. 10 An evaluation of grizzly bear-human conflict in the Northwest Boreal Region of Alberta (1991-2000) and potential mitigation, by T. Augustyn. (2001)

No. 11 Harlequin duck monitoring in the Northern East Slopes of Alberta: 1998-2000 preliminary results, by J. Kneteman and A. Hubbs. (2000)

No. 12 Distribution of selected small mammals in Alberta, by L. Engley and M. Norton. (2001)

No. 13 Northern leopard frog reintroduction. Raven River - Year 2 (2000), by K. Kendell. (2001)

No. 14 Cumulative effects of watershed disturbances on fish communities in the Kakwa and Simonette watersheds. The Northern Watershed Project. Study 3 Progress report, by T. Thera and A. Wildeman. (2001)

No. 15 Harlequin duck research in Kananaskis Country in 2000, by C.M. Smith. (2001)

No. 16 Proposed monitoring plan for harlequin ducks in the Bow Region of Alberta, by C.M. Smith. (2001)

No. 17 Distribution and relative abundance of small mammals of the western plains of Alberta as determined from great horned owl pellets, by D. Schowalter. (2001)

No. 18 Western blue flag (Iris missouriensis) in Alberta: a census of naturally occurring populations for 2000, by R. Ernst. (2000)

No. 19 Assessing chick survival of sage grouse in Canada, by C.L. Aldridge. (2000)

No. 20 Harlequin duck surveys of the Oldman River Basin in 2000, by D. Paton. (2000)

No. 21 Proposed protocols for inventories of rare plants of the Grassland Natural Region, by C. Wallis. (2001) 
No. 22 Utilization of airphoto interpretation to locate prairie rattlesnake (Crotalus viridis viridis) hibernacula in the South Saskatchewan River valley, by J. Nicholson and S. Rose. (2001)

No. 23 2000/2001 Progress report on caribou research in west central Alberta, by T. Szkorupa. (2001)

No. 24 Census of swift fox (Vulpes velox) in Canada and Northern Montana: 2000-2001, by A. Moehrenschlager and C. Moehrenschlager. (2001)

No. 25 Population estimate and habitat associations of the long-billed curlew in Alberta, by E.J. Saunders. (2001)

No. 26 Aerial reconnaissance for piping plover habitat in east-central Alberta, May 2001, by D.R.C. Prescott. (2001)

No. 27 The 2001 international piping plover census in Alberta, by D.R.C. Prescott. (2001) 
National Library of Canada
Bibliothèque Bibliotheque nationale du Canada

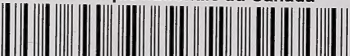

33286524750193 